Ekonomia - Wroclaw Economic Review 24/3 (2018)

Acta Universitatis Wratislaviensis

No 3881

DOI: 10.19195/2084-4093.24.3.8

\author{
Agnieszka Sadowa \\ ORCID: 0000-0003-4672-0356 \\ Uniwersytet Wrocławski \\ sadowaagnieszka1@gmail.com
}

\title{
Warunki mieszkaniowe jako wyznacznik jakości życia osób niepełnosprawnych na przykładzie osób z dysfunkcją narządu wzroku
}

Artykuł nadesłany: 1 sierpnia 2018 r.; artykuł zaakceptowany: 10 września 2018 r.

JEL Classification: D31, I14, I38, J14, R21

Keywords: disability, sight dysfunction, quality of life, housing conditions, housing needs

\begin{abstract}
Housing conditions as a determinant of the quality of life of disabled people, based on the example of people with sight dysfunction
\end{abstract}

One of the basic needs of a person is to have a place to live. Virtually everyone dreams of having their own place, to relax and feel safe. Such a space is an important place for people with disabilities, because it is often the only place that is tailored to their needs, where they feel safer than in any other spaces. Every citizen of the country has the right to housing, which is provided by numerous documents and regulations.

The purpose of this article is to evaluate the impact of housing conditions on the quality of life of people with disabilities. The following thesis has been formulated in the work: the disabled aim to improve the quality of their lives by changing housing conditions.

Literature sources have been reviewed to define basic concepts, the results of previous studies have been correlated. After accessing the database, the results of the research carried out in March 2015 by the foundation "Nie widzę problemu" (literally meaning "I do not see the problem") with involvement of employees and students of the University of Wroclaw have been compiled.

The analysis shows that respondents most often live together with their parents and spend a large part of their income on purchases related to household appliances. As much as $60 \%$ of respondents do not own a flat. Approximately $68 \%$ find the buildings they live in are not suited to their needs, however only $23 \%$ of them try to get social housing.

Translated by Karolina Riemel 


\section{Wstęp}

Dane zebrane podczas Narodowego Spisu Powszechnego w 2011 roku wskazują, że w Polsce zamieszkiwało wtedy niemal 4,7 mln osób niepełnosprawnych według kryterium biologicznego oraz ponad 3,1 mln osób posiadało orzeczenie o niepełnosprawności. Oznacza to, że co dwunasty mieszkaniec Polski ma orzeczenie o niepełnosprawności (GUS, 2011). Potrzeby osób niepełnosprawnych są zróżnicowane i zależą od rodzaju i stopnia niepełnosprawności. Jest jednak pewna grupa potrzeb ważna dla wszystkich osób niepełnosprawnych — zapewnienie odpowiedniej sytuacji materialno-bytowej. Ponadto są to: praca, przyrządy pomagające funkcjonować w niepełnosprawności, zdrowie, rehabilitacja fizyczna oraz przystosowanie mieszkania (Badanie potrzeb osób niepełnosprawnych, 2017, s. 72).

Posiadanie mieszkania jest podstawową potrzebą każdego człowieka zarówno pełnosprawnego, jak i niepełnosprawnego. O prawie do mieszkania mówią takie dokumenty, jak: Powszechna deklaracja praw człowieka, Europejska karta społeczna czy Konstytucja RP. Dodatkowo osoby niepełnosprawne potrzebują odpowiednich warunków mieszkaniowych pozwalających na swobodne funkcjonowanie w tej przestrzeni. Temat warunków mieszkaniowych, które wpływają na jakość życia, wydaje się bardzo ważny i godny uwagi.

Celem niniejszego artykułu jest ocena wpływu warunków mieszkaniowych na jakość życia osób niepełnosprawnych na przykładzie osób z dysfunkcją narządu wzroku. Analizę zagadnienia oparto na wynikach badań przeprowadzonych w 2015 roku w siedzibie Fundacji „Nie widzę problemu” we Wrocławiu. Podmiotem badań były osoby z orzeczeniem o niepełnosprawności z dysfunkcją narządu wzroku, zamieszkałe na Dolnym Śląsku. Przedmiotem badań było określenie poziomu życia osób z dysfunkcją narządu wzroku. Po badaniach fokusowych i pilotażowych przeprowadzono badania właściwe na grupie 129 respondentów. Autorka nie przeprowadzała badan, a opracowała ich wyniki. W niniejszym artykule zostanie przedstawiony fragment opisanych badań, powiązany z tematem mieszkań. W pracy sformułowano następującą hipotezę badawczą: niepełnosprawni dążą do poprawy jakości swojego życia poprzez zmianę warunków mieszkaniowych.

\section{Teoretyczne ujęcie potrzeby, jakości życia oraz osoby niepełnosprawnej}

Rozważania na temat potrzeb mieszkaniowych osób niepełnosprawnych należy rozpocząc do zdefiniowania podstawowych pojęć: potrzeby, jakości życia oraz osoby niepełnosprawnej.

Literatura ekonomiczna wskazuje definicję po trzeby jako „stanu braku czegoś i zarazem czynnika uruchamiającego funkcję motywu działania w kierunku odpowiedniej zmiany tego stanu" (Hołub, Perenc, Rosa, 1997, s. 85). 
Nieskończona jest lista potrzeb człowieka. Ludzie natomiast posiadają ograniczone środki, dlatego niemożliwe jest zaspokojenie wszystkich odczuwanych potrzeb. Tak zwana hierarchia potrzeb jest przyporządkowaniem potrzeb zgodnie z kryterium pilności, a pilność przesądza o zaspokajaniu potrzeb podstawowych w pierwszej kolejności oraz potrzeb wyższych rzędów następnie. Powszechnie przyjętym podziałem potrzeb człowieka jest hierarchia potrzeb według amerykańskiego psychologa Abrahama Maslowa (Rudnicki, 2004, s. 42-43). Zaczynając od potrzeb najniższego rzędu, wyodrębnia się (Maslow, 1954, s. 35-47):

1. potrzeby fizjologiczne wynikające z wymagań organizmu ludzkiego, na przykład głód, sen;

2. potrzeby bezpieczeństwa obejmujące dążenie do stabilizacji i spokoju oraz unikania zagrożenia, na przykład stałość (zamieszkania, miejsca pracy), pewność, opieka, porządek;

3. potrzeby przynależności i miłości oznaczające możliwość okazywania oraz odbierania uczuć od innych ludzi, na przykład miłość, czułość, akceptacja;

4. potrzeby szacunku wiążą się z posiadaniem kompetencji zapewniających prestiż, pozwalających wyróżnić się spośród innych, zyskać podziw i uznanie otoczenia, osiągnąc sukces;

5. potrzeby samorealizacji jako dążenia do najlepszego wykorzystania swoich umiejętności i talentów, realizacji życiowych planów i spełniania marzeń (na przykład posiadanie domu z ogródkiem).

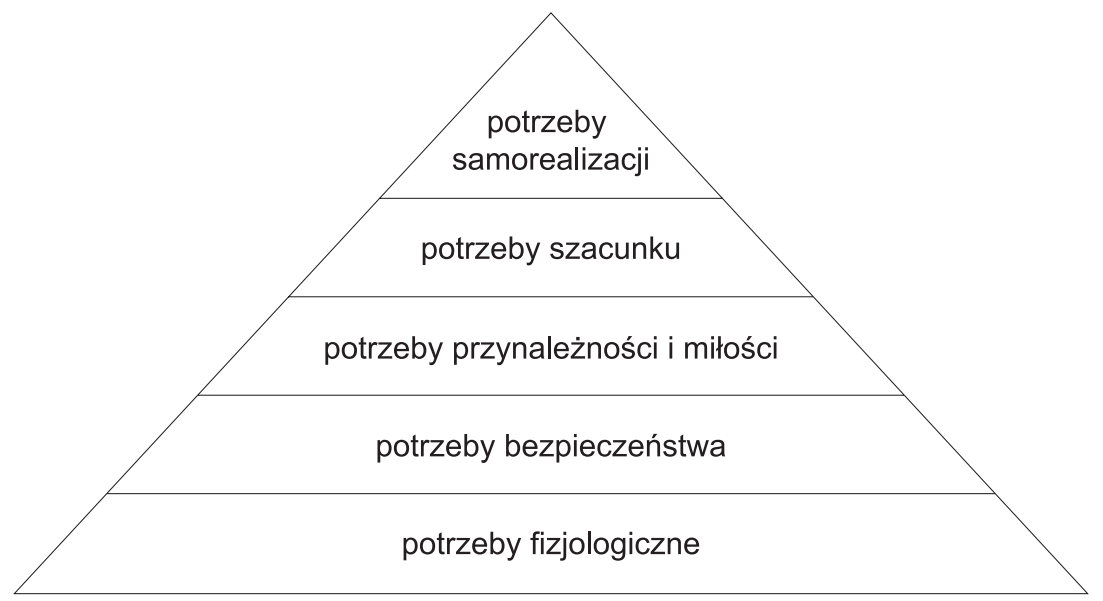

Rysunek 1. Hierarchia potrzeb Maslowa

Źródło: opracowanie własne na podstawie A.H. Maslow (1954, s. 35-47).

Maslow dostrzegł, iż niemożliwe jest odczuwanie potrzeb wyższego rzędu, jeśli potrzeby niższych rzędów (podstawowe) pozostają niezaspokojone. Gdy 
człowiek od dłuższego czasu odczuwa głód, nie myśli o potrzebach wyższych rzędów, takich jak przykładowo prestiż (Perenc, Rosa, (red.), 2011, s. 47).

Pojęcie jakości życia ściśle wiąże się ze stopniem zaspokojenia potrzeb. Należy zaznaczyć, że pojęcie to ewoluowało przez dziesięciolecia oraz że istnieje wiele jego definicji. Bywalec i Rudnicki (1999, s. 26) piszą, iż ,jakość życia to stan satysfakcji, szczęścia, zadowolenia płynący z całokształtu egzystencji”. Jakość życia można definiować przez wymiar obiektywny i subiektywny. Obiektywny odnosi się do zjawisk, na które jednostka nie ma wpływu, na przykład struktura społeczno-ekonomiczna. Subiektywny to między innymi aspiracje i oczekiwania osoby (Skrzypek, 2018). Jakość życia według Kolmana (2000, s. 2) to

stopień zaspokojenia potrzeb duchowych i materialnych człowieka, stopień zaspokojenia wymagań określający poziom materialnego i duchowego bytu jednostek i całego społeczeństwa, stopień spełnienia oczekiwań umownej normalności w działaniach i sytuacji codziennego życia jednostek i społeczeństwa.

Interesującą metodą pozwalającą ocenić jakość życia jest Międzynarodowa Klasyfikacja Funkcjonowania, Niepełnosprawności i Zdrowia (ICF) składająca się z dwóch części: funkcjonowanie i niepełnosprawność oraz czynniki kontekstowe (Wilmowska-Pieteuszyńska, Bilski, 2010, s. 4).

Przechodząc do pojęcia niepełnosprawności i osoby niepełnosprawnej, należy zaznaczyć, iż nigdy nie opracowano jednej obowiązującej wszędzie definicji niepełnosprawności. Wielu autorów i instytucji zdecydowało się scharakteryzować niepełnosprawność i pojęcie osoby niepełnosprawnej.

Szawłowski i Chojnacka-Szawłowska (1990, s. 18) za osoby niepełnosprawne uważają te, które

na skutek wad lub chorób wrodzonych oraz chorób nabytych w różnym okresie życia doznały naruszenia czynności narządów, układów lub całego organizmu, co ogranicza w różnym stopniu ich funkcjonowanie biologiczne i (lub) społecznym.

Hulek (1992, s. 24-25) podaje, że

za osobę niepełnosprawną uznać należy osobę, której stan fizyczny lub psychiczny trwale lub okresowo utrudnia, ogranicza albo uniemożliwia wypełnianie zadań życiowych i ról społecznych zgodnie z normami społecznymi i prawnymi.

Zgodnie z definicją sformułowaną przez Światową Organizację Zdrowia (WHO): osoba niepełnosprawna to osoba, u której istotne uszkodzenia i obniżenie sprawności funkcjonowania organizmu powodują uniemożliwienie, utrudnienie lub ograniczenie sprawnego funkcjonowania $\mathrm{w}$ społeczeństwie, biorąc pod uwagę takie czynniki, jak płeć, wiek oraz czynniki zewnętrzne (Rzempowska, 2011, s. 14)

Ustawa z dnia 27 sierpnia 1997 roku o rehabilitacji zawodowej i społecznej oraz zatrudnianiu osób niepełnosprawnych (Dz.U. 1997 Nr 123, poz. 776) w art. 2 pkt 10 definiuje niepełnosprawność jako „trwałą lub okresową niezdolność 
do wypełniania ról społecznych z powodu stałego lub długotrwałego naruszenia sprawności organizmu, w szczególności powodującą niezdolność do pracy”. Artykuł 3 wskazuje na trzy stopnie niepełnosprawności:
1. znaczny,
2. umiarkowany,
3. lekki.

Biorąc pod uwagę rodzaj niepełnosprawności, Majewski (1995, s. 22) wyróżnia następujące klasyfikacje osób niepełnosprawnych:

1. osoby z niepełnosprawnością fizyczną to te, u których występuje uszkodzenie, zaburzenie, choroba narządu ruchu lub niektóre zaburzenia mowy;

2. osoby z niepełnosprawnością sensoryczną (zmysłową), czyli niewidomi, niedowidzący, niesłyszący, niedosłyszący;

3. osoby z niepełnosprawnością psychiczną lub umysłową, a więc osoby z zaburzeniami i chorobami psychicznymi, z upośledzeniem umysłowym i $z$ autyzmem;

4. osoby z niepełnosprawnością społeczną to te, u których występują zaburzenia równowagi nerwowej, emocjonalnej i zdrowia psychicznego;

5. osoby z niepełnosprawnością złożoną, dotknięte więcej niż jedną niepełnosprawnością.

\section{Prawo do dachu nad głową}

Nikt nie podważa stwierdzenia, iż w hierarchii potrzeb człowieka mieszkanie zajmuje czołową pozycję. Własny kąt jest podstawową potrzebą każdego człowieka, a prawo do niego ma każdy obywatel. Prawo do mieszkania zostało zawarte w deklaracjach światowych, regulacjach Unii Europejskiej, a także w polskim ustawodawstwie narodowym (Lis, 2015, s. 5). Pierwszym dokumentem, w którym sformułowano prawo do mieszkania była Powszechna deklaracja praw człowieka wydana przez Organizację Narodów Zjednoczonych w 1948 roku. Zgodnie z 25 artykułem tego dokumentu

Każdy człowiek ma prawo do stopy życiowej zapewniającej zdrowie i dobrobyt jego i jego rodziny, włączając $\mathrm{w}$ to wyżywienie, odzież, mieszkanie, opiekę lekarską i konieczne świadczenia socjalne, oraz prawo do ubezpieczenia na wypadek bezrobocia, choroby, niezdolności do pracy, wdowieństwa, starości lub utraty środków do życia w inny sposób od niego niezależny.

W tabeli 1 przedstawiono inne ważne dokumenty, które zawierają koncepcję prawa do mieszkania, oraz ich treści. Są to między innymi Międzynarodowy pakt praw ekonomicznych, społecznych i kulturalnych, Międzynarodowa konwencja o prawach dziecka czy europejska karta społeczna. 
Tabela 1. Dokumenty międzynarodowe dotyczące prawa do mieszkania

\begin{tabular}{|c|c|c|c|}
\hline Nazwa dokumentu & Podmiot & $\begin{array}{c}\text { Data } \\
\text { uchwalenia }\end{array}$ & Treść \\
\hline $\begin{array}{l}\text { Powszechna } \\
\text { deklaracja praw czło- } \\
\text { wieka }\end{array}$ & ONZ & 1948 rok & $\begin{array}{l}\text { Artykuł 25. Każdy człowiek ma prawo do ży- } \\
\text { cia na poziomie zapewniającym zdrowie i po- } \\
\text { myślność jemu i jego rodziny, włączając w to } \\
\text { wyżywienie, odzież, mieszkanie, opiekę lekar- } \\
\text { ską oraz niezbędne świadczenia socjalne [...]. }\end{array}$ \\
\hline $\begin{array}{l}\text { Międzynarodowy pakt } \\
\text { praw ekonomicznych, } \\
\text { społecznych } \\
\text { i kulturalnych }\end{array}$ & ONZ & 1966 rok & $\begin{array}{l}\text { Artykuł 11. Poszczególne kraje zawierające ni- } \\
\text { niejszą umowę uznają prawo każdego obywa- } \\
\text { tela do życia jego i jego rodziny na poziomie } \\
\text { wyznaczonym przez odpowiedni standard włą- } \\
\text { czając w to wyżywienie, odzież i mieszkanie, } \\
\text { zakładając przy tym ciągłą poprawę warunków } \\
\text { ich życia. }\end{array}$ \\
\hline $\begin{array}{l}\text { Deklaracja dotycząca } \\
\text { postępu społecznego } \\
\text { i rozwoju }\end{array}$ & ONZ & 1969 rok & $\begin{array}{l}\text { Artykuł 10. Zapewnienie podstawowych wol- } \\
\text { ności człowieka może zostać osiągnięte przez } \\
\text { dostarczenie wszystkim, w tym szczególnie } \\
\text { najbiedniejszym, oraz wielodzietnym rodzi- } \\
\text { nom odpowiedniego mieszkania i usług spo- } \\
\text { łecznych. }\end{array}$ \\
\hline $\begin{array}{l}\text { Międzynarodowa } \\
\text { konwencja o prawach } \\
\text { człowieka }\end{array}$ & ONZ & 1989 rok & $\begin{array}{l}\text { Artykuł } 27 \text { pkt } 3 \text {. Poszczególne kraje, uwzględ- } \\
\text { niając swoje warunki i możliwości finansowe, } \\
\text { zobowiązują się do pomocy rodzicom i innym } \\
\text { osobom odpowiedzialnym za dziecko, poprzez } \\
\text { wsparcie materialne i programy pomoco- } \\
\text { we, w szczególności w zakresie wyżywienia, } \\
\text { odzieży i mieszkania. }\end{array}$ \\
\hline $\begin{array}{l}\text { Europejska karta } \\
\text { społeczna z późn. zm. }\end{array}$ & $\begin{array}{l}\text { Rada } \\
\text { Europy }\end{array}$ & $\begin{array}{l}1961 \text { rok } \\
\text { zmiany } \\
\text { z } 1996 \text { roku }\end{array}$ & $\begin{array}{l}\text { 1. Promowania dostępu do mieszkalnictwa } \\
\text { w odpowiednim standardzie; } \\
\text { 2. Zapobiegania i redukowania bezdomności } \\
\text { w kierunku jego stopniowego eliminowania; } \\
\text { 3. Zwiększania możliwości nabycia mieszka- } \\
\text { nia przez obywateli nie dysponujących dosta- } \\
\text { tecznymi zasobami finansowymi. }\end{array}$ \\
\hline $\begin{array}{l}\text { Deklaracja konwencji } \\
\text { Habitat II w Istambule }\end{array}$ & ONZ & 1996 rok & $\begin{array}{l}\text { Poszczególne kraje zobowiązują się do pełnej } \\
\text { i postępującej realizacji prawa do odpowiednie- } \\
\text { go mieszkania zgodnie z postanowieniami do- } \\
\text { kumentów międzynarodowych oraz zapewnie- } \\
\text { nia równego dostępu do tanich i odpowiednich } \\
\text { mieszkań wszystkim osobom i ich rodzicom. }\end{array}$ \\
\hline
\end{tabular}

Źródło: Lis (2005).

W Polsce podstawowym aktem regulującym prawo obywateli do mieszkania jest Konstytucja RP z 2 kwietnia 1997 roku. W art. 75 mowa jest o ochronie lokatorów i polityce zaspokajania potrzeb mieszkaniowych: 
1. Władze publiczne prowadzą politykę sprzyjającą zaspokojeniu potrzeb mieszkaniowych obywateli, w szczególności przeciwdziałają bezdomności, wspierają rozwój budownictwa socjalnego oraz popierają działania obywateli zmierzające do uzyskania własnego mieszkania.

2. Ochronę praw lokatorów określa ustawa.

Także gminy mają zobowiązania w zakresie zaspokajania potrzeb mieszkaniowych. W art. 7 ustawy o samorządzie gminnym (Dz.U. 1990 Nr 16, poz. 95) mówi się o obowiązku gmin do zaspokajania zbiorowych potrzeb wspólnoty. Jednym z zadań własnych wspólnoty jest gminne budownictwo mieszkaniowe.

Ustawa o ochronie praw lokatorów, mieszkaniowym zasobie gminy i o zmianie Kodeksu cywilnego (Dz.U. $2001 \mathrm{Nr} 71$, poz. 733) również nawiązuje do prawa mieszkańców gminy do dachu nad głową. Zgodnie z art. 4 pkt 2

Gmina, na zasadach i w wypadkach przewidzianych w ustawie, zapewnia lokale socjalne i lokale zamienne, a także zaspokaja potrzeby mieszkaniowe gospodarstw domowych o niskich dochodach.

„Do zadań własnych gminy o charakterze obowiązkowym należy [...] udzielenie schronienia [...] osobom tego pozbawionym", o czym mówi art. 17 ustawy o pomocy społecznej (Dz.U. $2004 \mathrm{Nr}$ 64, poz. 593).

Warto również wspomnieć o przepisach regulujących dostosowanie budynków do potrzeb osób niepełnosprawnych, które znajdują się w Rozporządzeniu Ministra Infrastruktury z dnia 12 kwietnia 2002 roku w sprawie warunków technicznych, jakim powinny odpowiadać budynku i ich usytuowanie (Dz.U. 2002 $\mathrm{Nr} 75$, poz. 690). Na przykład w dziale II znajdują się wytyczne dotyczące usytuowania budynku oraz dojść i dojazdów, a w dziale III omówiono wymagania dla budynku i jego pomieszczeń.

\section{Potrzeby mieszkaniowe osób niepełnosprawnych}

Pełne dane na temat zagadnienia niepełnosprawności zebrano ostatnio w ramach Narodowego Spisu Powszechnego w 2011 roku. Informacji na temat osób niepełnosprawnych dostarczają także inne badania Głównego Urzędu Statystycznego.

Dane wskazują, że w Polsce w 2011 roku zamieszkiwało niemal 4,7 mln osób niepełnosprawnych według kryterium biologicznego, a 67\% z nich (ponad 3,1 mln osób) miało orzeczenie o niepełnosprawności. Oznacza to, że co dwunasty mieszkaniec Polski ma orzeczenie o niepełnosprawności. Najwięcej (38\%) osób niepełnosprawnych miało orzeczenie o umiarkowanym stopniu niepełnosprawności (GUS, 2011). Według danych GUS z 2014 roku najczęściej występującym rodzajem niepełnosprawności są uszkodzenia i choroby narządu ruchu. Dotyczą one $59 \%$ osób niepełnosprawnych zarówno prawnie, jak i biologicznie (GUS, 2014).

Jedną z najważniejszych potrzeb człowieka jest posiadanie dachu na głową, a podstawową potrzebą mieszkaniową jest dysponowanie własnościowym mieszkaniem/domem, co nazwane zostało potrzebą ilościową. Do jakościowych potrzeb 
mieszkaniowych zalicza się: wielkość mieszkania, jego standard, funkcjonalność oraz poczucie bezpieczeństwa. Mieszkanie osoby niepełnosprawnej powinno umożliwić jej warunki do realizacji wszystkich potrzeb charakterystycznych dla wszystkich osób, także pełnosprawnych. Przestrzeń ruchu osób z dysfunkcją narządu wzroku jest oczywiście uzależniona od rodzaju i stopnia schorzenia. Najważniejszy jest jednak układ funkcjonalno-przestrzenny powierzchni mieszkaniowej, który ma umożliwiać łatwą orientację i poruszanie się w przestrzeni, a jego wyposażenie meblarskie powinno zapewniać uporządkowanie i szybki dostęp do trzymanych w mieszkaniu dokumentów, przedmiotów, pamiątek. Dużą rolę odgrywa tutaj także oświetlenie (Nowakowski, Charytonowicz).

W XXI wieku bardzo dużo mówi się o potrzebach osób niepełnosprawnych, jednak jakie są te potrzeby, najlepiej wiedzą sami niepełnosprawni.

Przeprowadzono wiele badań wśród osób z niepełnosprawnością. Wyniki badań Parchomiuk i Byra (2006, s. 30) pokazały, że osoby słabowidzące miały najwyższe wyniki w zakresie jakości życia.

Garbat i Paszkowicz w celu oceny życia osób niepełnosprawnych mieszkających na terenie województwa lubuskiego przebadały 182 osoby. Większość osób biorących udział $\mathrm{w}$ badaniu jest zadowolona ze swojego miejsca zamieszkania. Respondenci wskazywali, że nie zamieniliby swojego mieszkania oraz jego wyposażenia na inne. Mieszkanie własnościowe najczęściej posiadali pracujący niepełnosprawni, bezrobotni natomiast zamieszkują lokale czynszowe. Lokale osób mieszkających na wsi zazwyczaj były większe od tych mieszkających w mieście. Najczęściej jednak wskazywano na takie, które składały się z dwóch i trzech pokoi. Cieszy to, że większość respondentów posiadała swój własny pokój. Zasmuca jednak fakt, że wiele osób z dysfunkcją ruchu wskazała na brak dostosowania budynku do ich potrzeb, na przykład brak windy, pochylni czy mechanizmów opóźniających zamykanie drzwi. Osoby niewidome wskazały w swoich mieszkaniach takie niedogodności, jak: zbyt małą przestrzeń oraz niedostosowanie przedmiotów codziennego użytku, co wyklucza badanych z ich korzystania (Pawłowska, 2009, s. 16).

Badania warunków mieszkaniowych osób niepełnosprawnych obszarów wiejskich przeprowadzały Siedlecka i Smarzewska (2013, s. 160-164). Na terenach wiejskich przeważają domy jednorodzinne i ponad $70 \%$ respondentów takie domy zamieszkiwało. Średnia powierzchnia użytkowa gospodarstw domowych z osobą niepełnosprawną wynosiła około $83 \mathrm{~m}^{2}$ i była wyższa od średniej powierzchni użytkowej w Polsce w 2011 roku $\left(69,2 \mathrm{~m}^{2}\right)$. Cieszy, że średnia powierzchnia na osobę w badanej grupie wynosiła ponad $73 \mathrm{~m}^{2}$. Na jakość życia niepełnosprawnych wpływa także liczba izb w lokalu. W tych badaniach kształtowała się ona na poziomie 4,33 .

Pomiaru jakości życia osób z dysfunkcją narządu wzroku podjęli się Rosińczuk, Szalonka, Fugowska i Sikora (2015, s. 139-140). Z badań wynika, że 60\% osób oceniło swój poziom życia jako średni i wysoki, natomiast 30\% jako niski i skrajnie niski. Ponadto $30 \%$ osób z dysfunkcją wzroku odczuło w ostatnim roku 
polepszenie swojej sytuacji, a $20 \%$ - pogorszenie. Pomimo dysfunkcji wzroku prawie $60 \%$ osób jest zadowolonych ze swojego życia, a jako najważniejsze przy jego ocenie wymieniano: zdrowie osobiste i członków rodziny $(80 \%)$, stabilną pracę (56\%), możliwość realizacji marzeń (50\%), życie rodzinne (50\%), miłość (46\%) oraz wysokie dochody zapewniające stabilne życie (37\%).

Państwowy Fundusz Rehabilitacji Osób Niepełnosprawnych zlecił w 2017 roku wykonanie badań, które miały na celu zdiagnozowanie potrzeb osób niepełnosprawnych z ich własnego punktu widzenia, a następnie identyfikacji możliwego dla tych osób wsparcia. Badaniem objęto także potrzeby mieszkaniowe. $\mathrm{Z}$ uzyskanych danych stworzono hierarchię potrzeb osób niepełnosprawnych. $\mathrm{Na}$ pierwszym miejscu znalazła się sytuacja materialna. Aż 16\% badanych przypisało tej potrzebie pierwszą pozycję. Na pozycji szóstej znalazła się potrzeba przystosowania mieszkania - pierwszą pozycję przypisało tej potrzebie $6 \%$ respondentów (najczęściej były to osoby z dysfunkcją ruchu $-9 \%$ i dysfunkcją wzroku $-3 \%$ ). Dla ogółu respondentów, jak i dla grupy osób z dysfunkcją narządu wzroku, trzynasta $\mathrm{z}$ rzędu była potrzeba poprawy warunków mieszkaniowych (Badanie potrzeb osób niepełnosprawnych, 2017, s. 76-79).

Większość respondentów dzieli gospodarstwo domowe z innymi osobami. $57 \%$ mieszka samodzielnie z własną rodziną, a $25 \%$ z rodzicami lub opiekunami. Biorąc pod uwagę osoby z dysfunkcją wzroku, aż $60 \%$ mieszka samodzielnie, z własną rodziną, a tylko $16 \%$ to osoby samotne. Jeśli chodzi o wielkość gospodarstwa domowego osób niepełnosprawnych ogółem, to 54\% badanych mieszka w gospodarstwach trzyosobowych i większych, w wypadku osób niewidomych i niedowidzących jest podobnie $-53 \%$. Ponad $50 \%$ osób z dysfunkcją wzroku, które mieszkają z opiekunami deklarowała, iż chciałaby mieszkać samotnie. Respondenci oceniali także swoje warunki mieszkaniowe: $48 \%$ ocenia je jako bardzo dobre i raczej dobre. W przypadku osób z dysfunkcją wzroku jest to o 1 punkt procentowy więcej od ogólnej średniej (49\%). Respondenci zapytani o przystosowanie mieszkania do ich potrzeb w $43 \%$ odpowiadali, że są one całkowicie lub w dużym stopniu przystosowane (zarówno niepełnosprawni ogółem, jak i niewidomi i słabowidzący). Osoby z dysfunkcją wzroku zgłaszały jednak zapotrzebowanie na większe mieszkanie, wyrównanie podług czy montaż odpowiedniego oświetlenia (Badanie potrzeb osób niepełnosprawnych, 2017, s. 104-119).

Dębicka, Mazurek, Szalonka (2017, s. 39-40) przeprowadziły analizę statystyczną celem zidentyfikowania czynników mających wpływ (statystycznie istotny) na poczucie zadowolenia z życia osób niepełnosprawnych fizycznie i psychicznie. Dla tych osób szczególnie ważne okazały się kwestie dotyczące finansów: posiadany majątek oraz poprawa sytuacji materialnej w ciągu ostatnich pięciu lat. Zaobserwowano, że osoby majętne mają czterokrotnie większą szansę na zadowolenie z życia w porównaniu do osób oceniających swój stan majątkowy jako niski. Polepszenie sytuacji materialnej na przestrzeni ostatnich pięciu lat osiemnastokrotnie podnosi szansę takiego zadowolenia. 


\section{Ocena jakości życia osób z dysfunkcją narządu wzroku w odniesieniu do warunków mieszkaniowych}

Analizę zagadnienia oparto na wynikach badań przeprowadzonych w 2015 roku w siedzibie Fundacji „Nie widzę problemu” we Wrocławiu. Podmiot badań stanowiły osoby z orzeczeniem o niepełnosprawności z dysfunkcją narządu wzroku, mieszkające na Dolnym Śląsku. Przedmiotem badań było określenie poziomu życia osób z dysfunkcją narządu wzroku. Badania przeprowadzono w celu identyfikacji obszarów, w których możliwa jest poprawa jakości życia osób niepełnosprawnych. Badania zrealizowano z ogromną precyzją i starannością. Na początku przeprowadzono badania fokusowe, w celu określenia obszarów wpływających na jakość życia niepełnosprawnych oraz budowy kwestionariusza do badań ilościowych. Następnie, w dniach 3-5 maja 2015 roku, przeprowadzono badania pilotażowe pozwalające na doprecyzowanie pytań kwestionariusza ankietowego. Kolejnym etapem były już badania właściwe, przeprowadzone w okresie od 15 maja do 3 czerwca 2015 roku. W badaniach tych wzięło udział 129 respondentów (jednak metryczkę wypełniło 117 osób, w tym 59 mężczyzn i 58 kobiet). Kwestionariusz podzielono na pięć dziedzin mających wpływ na jakość życia niepełnosprawnych. Były to: zdrowie, edukacja, sport, kultura oraz życie codzienne - zarówno w przestrzeni publicznej, jak i w domu.

W poniższej analizie zostanie przedstawiony wycinek opisanych badań, dotyczący oceny zdolności osób $z$ dysfunkcją narządu wzroku do zaspokajania potrzeb powiązanych z tematem mieszkań, czyli członkowie gospodarstwa domowego, posiadanie mieszkania/domu na własność, ubieganie się o mieszkanie socjalne, dostosowanie budynku i mieszkania do potrzeb respondentów, a także wydatków na zakup mieszkania/domu oraz sprzętu gospodarstwa domowego w ostatnich latach.

Respondenci najczęściej zamieszkiwali wraz z mężem (żoną) lub partnerem (partnerką) - jest to ponad 43\%. Prawie 30\% mieszka w rodzinie z dziećmi, a ponad $27 \%$ to osoby zamieszkujące samotnie (rysunek 2 ).

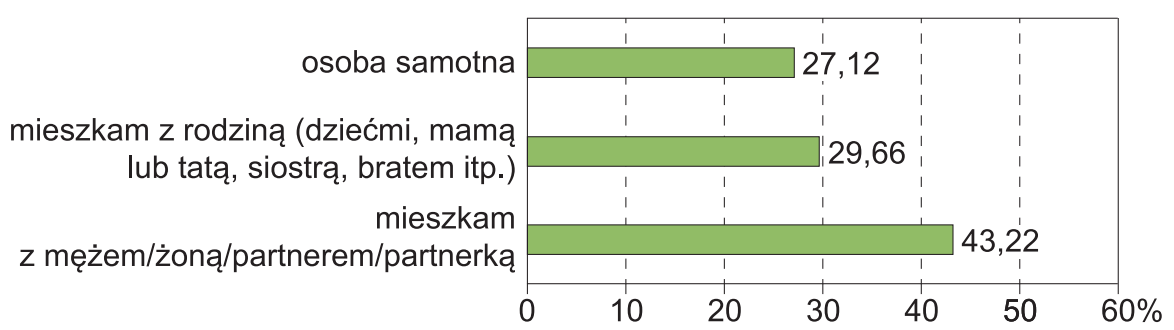

Rysunek 2. Gospodarstwo domowe osoby niepełnosprawnej

Źródło: opracowanie własne na podstawie badań przeprowadzonych w 2015 roku w siedzibie Fundacji „Nie widzę problemu”. 
Zapytano respondentów o zakupy, jakie zrobili w latach 2010-2014. Ponad połowa dotyczyła zakupu domu bądź mieszkania oraz zakupu sprzętu gospodarstwa domowego. Najwięcej osób w tych latach zakupiło drobny sprzęt gospodarstwa domowego (na przykład radio, mikser, odkurzacz) — prawie 35\%. Zakupu dużego sprzętu gospodarstwa domowego, takiego jak: telewizor, pralka, komputer dokonało ponad $24 \%$ respondentów; $5 \%$ z nich zakupiło mieszkanie, a 1,42\% zdecydowało się na zakup domu (rysunek 3).

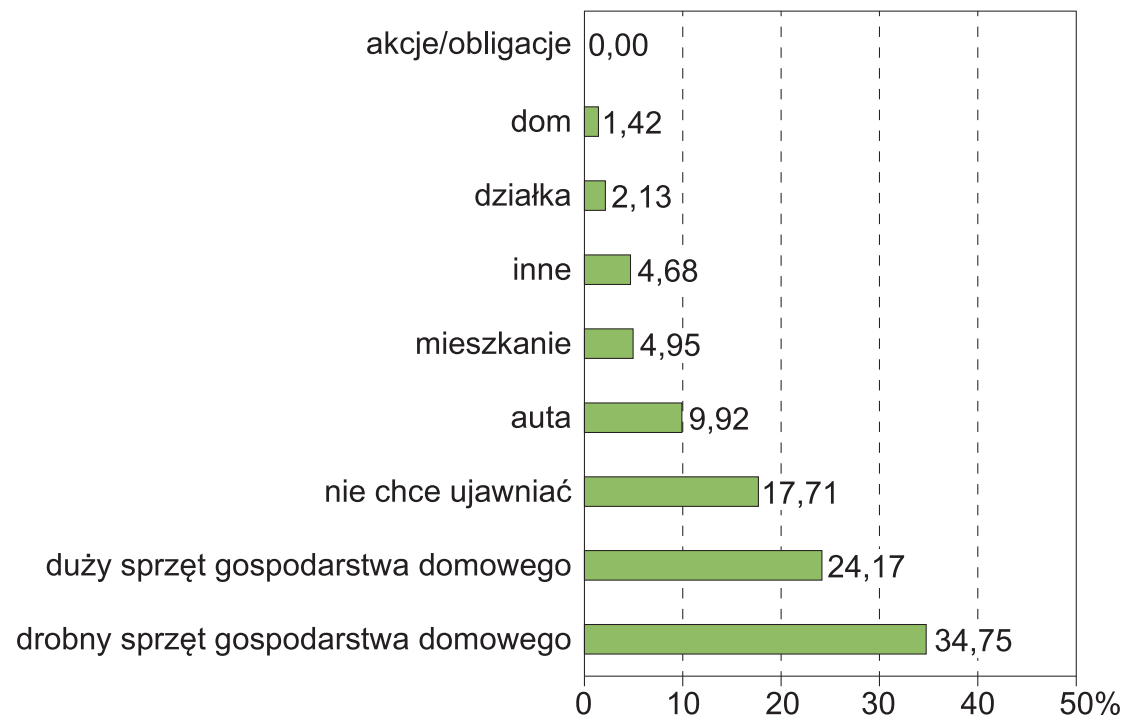

Rysunek 3. Zakupy dokonane w latach 2010-2014 (\%)

Źródło: opracowanie własne na podstawie badań przeprowadzonych w 2015 roku w siedzibie Fundacji „Nie widzę problemu”.

Kolejne pytanie dotyczyło posiadania mieszkania własnościowego. Warto zwrócić uwagę na ten problem, ponieważ z badań wynika, że tylko $40,54 \%$ badanych jest właścicielem/właścicielką takiego mieszkania, co oznacza, że prawie $60 \%$ respondentów nie zaspokaja podstawowej potrzeby mieszkaniowej, jaką jest posiadanie tak zwanych własnych czterech ścian. Tylko w grupie wiekowej 50-69 lat więcej osób posiada mieszkanie, niż nie posiada (ponad 59\%). Mieszkanie posiada także $40 \%$ osób w wieku od 31 do 49 lat i 32\% osób w wieku 21-30 lat ${ }^{1}$ (rysunek 4).

${ }^{1}$ Nie poddaje się analizie osób w wieku 70 lat i więcej, ponieważ na to pytanie odpowiedziały tylko trzy osoby w takim wieku. 


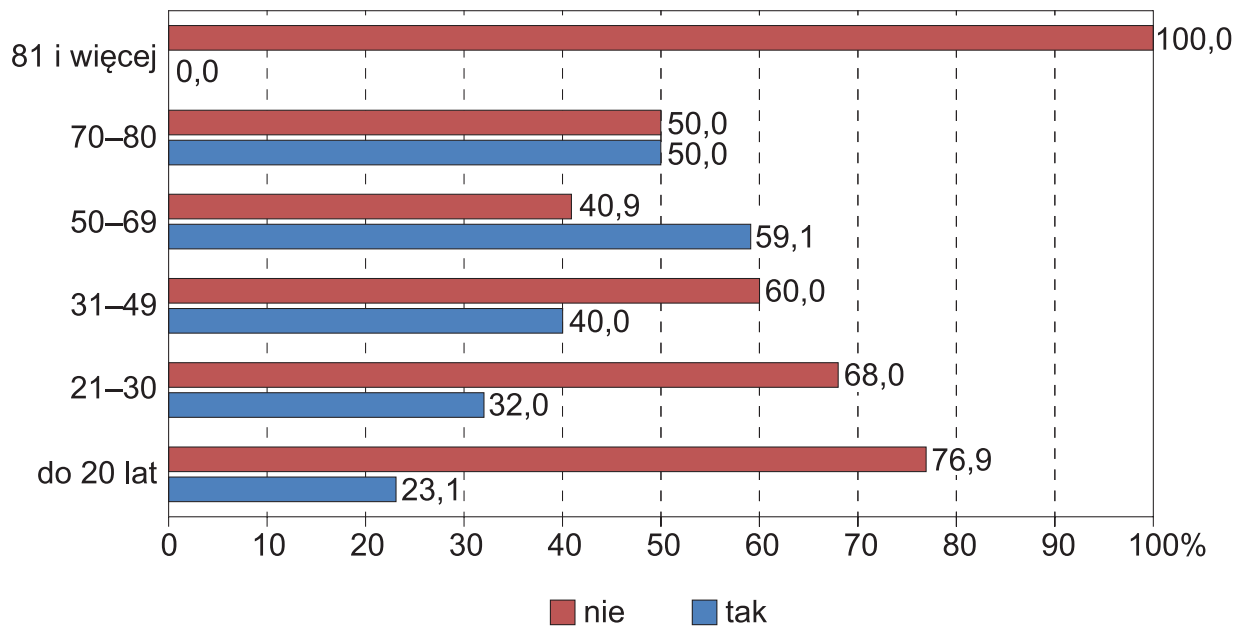

Rysunek 4. Posiadanie mieszkania własnościowego z podziałem na wiek respondentów (\%)

Źródło: opracowanie własne na podstawie badań przeprowadzonych w 2015 roku w siedzibie Fundacji „Nie widzę problemu”.

Pytanie dotyczące posiadania własnego mieszkania zweryfikowano również w podziale na wykształcenie osób z dysfunkcją narządu wzroku, co przedstawia rysunek 5 .

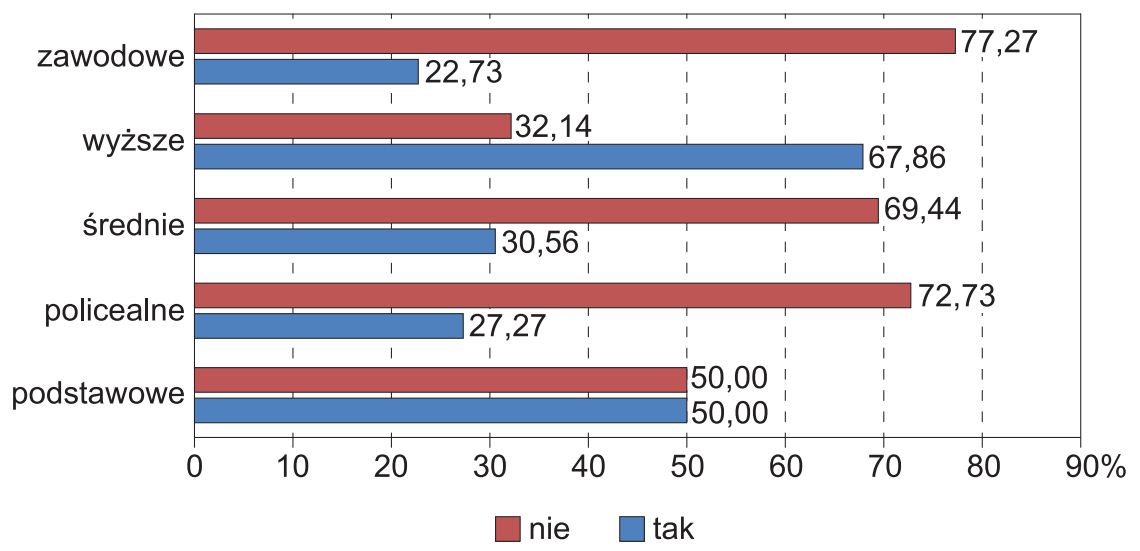

Rysunek 5. Posiadanie mieszkania własnościowego z podziałem na wykształcenie respondentów $(\%)$

Źródło: opracowanie własne na podstawie badań przeprowadzonych w 2015 roku w siedzibie Fundacji „Nie widzę problemu”.

Wśród respondentów, którzy posiadają własne mieszkanie, jedyną grupą, w której więcej osób posiada mieszkanie/dom na własność (niż nie posiada), są osoby z wykształceniem wyższym — jest to $68 \%$. Mieszkanie posiada także $50 \%$ osób z wykształceniem podstawowym. Najmniej liczą grupą wśród osób po- 
siadających własne mieszkanie są osoby z wykształceniem zawodowym (prawie $23 \%$ ) oraz policealnym (około $27 \%$ ).

Biorąc pod uwagę fakt, że posiadanie mieszkania jest podstawową potrzebą (szczególnie osób niepełnosprawnych) oraz badania, z których wynika, że aż 60\% osób z dysfunkcją narządu wzroku nie posiada własnego mieszkania lub domu, wydawać by się mogło, że wiele osób nieposiadających mieszkania będzie ubiegało się o mieszkanie socjalne. A co pokazują badania? Wśród osób, które nie posiadają mieszkania lub domu na własność (czyli z 60\% respondentów) tylko $23 \%$ ubiega się o przyznanie mieszkania socjalnego. Rysunek 6 przedstawia respondentów starających się o takie lokum z podziałem na wiek.

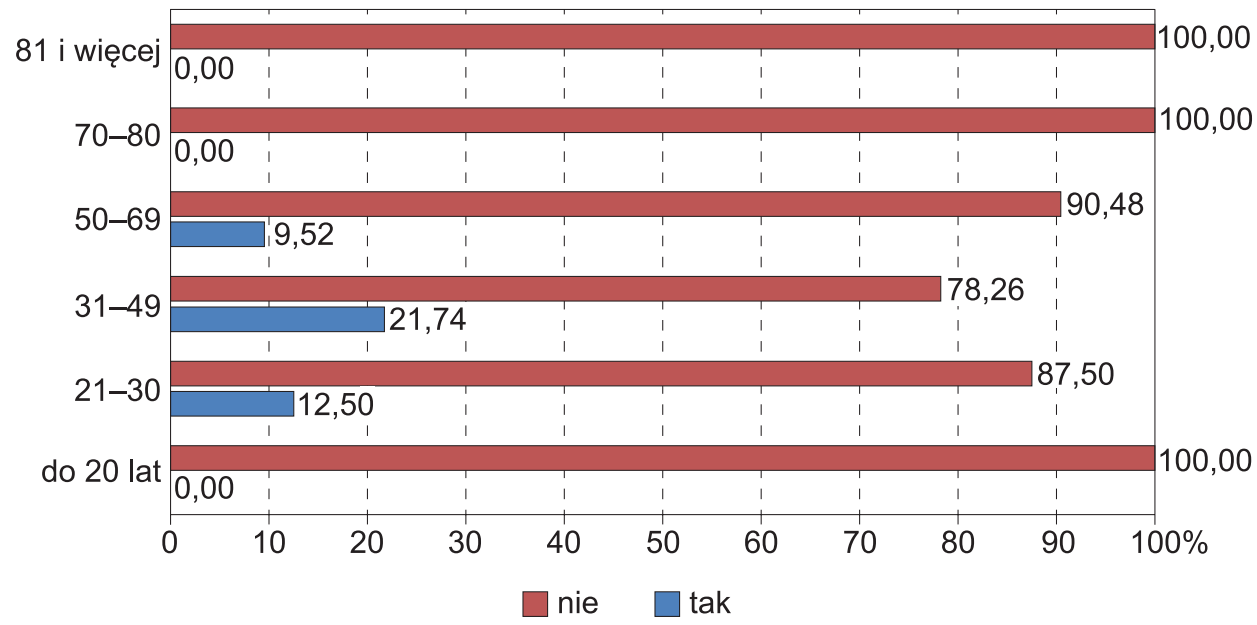

Rysunek 6. Respondenci starający się o przyznanie mieszkania socjalnego z podziałem na wiek $(\%)$

Źródło: opracowanie własne na podstawie badań przeprowadzonych w 2015 roku w siedzibie Fundacji „Nie widzę problemu”.

Najczęściej o mieszkania socjalne ubiegają się osoby w wieku od 31 do 49 lat i jest to prawie $22 \%$ tej grupy wiekowej, następnie osoby od 21 do 30 lat (12,5\%). Najmłodsi (do 20 roku życia) nie ubiegają się o takie mieszkanie, ale wynikać może to z faktu, że większość takich osób mieszka w domu rodziców, pod których są opieką ${ }^{2}$.

Z zebranych danych wynika, iż 30\% osób z wykształceniem policealnym, które nie posiadają swojego mieszkania (lub domu), stara się o mieszkanie socjalne. O takie lokum ubiega się prawie $19 \%$ osób z wykształceniem wyższym oraz ponad $14 \%$ z wykształceniem średnim. Tylko nieco ponad 4,5\% osób po szkole zawodowej podejmuje działania związane $\mathrm{z}$ chęcią posiadania mieszkania socjalnego (rysunek 7).

${ }^{2}$ Nie poddaje się analizie osób w wieku 70 lat i więcej, ponieważ na to pytanie odpowiedziały tylko trzy osoby w takim wieku. 


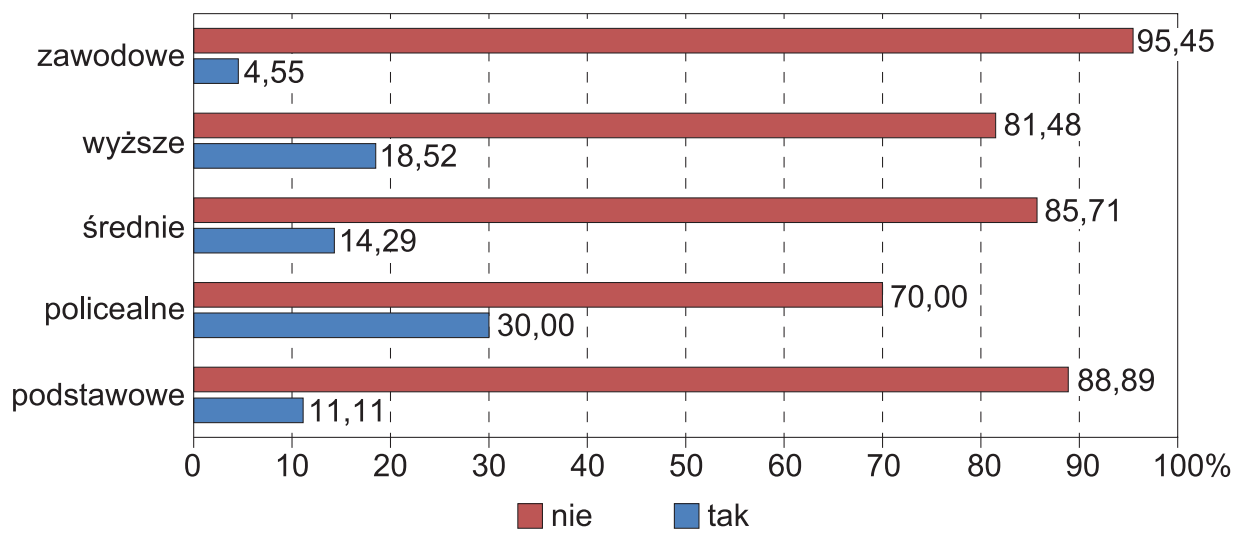

Rysunek 7. Respondenci starający się o przyznanie mieszkania socjalnego z podziałem na wykształcenie (\%)

Źródło: opracowanie własne na podstawie badań przeprowadzonych w 2015 roku w siedzibie Fundacji „Nie widzę problemu”.

W grupie pytań dotyczących życia codziennego respondentów poproszono o ocenę przystosowania budynku, który zamieszkują, do potrzeb osób niewidomych i słabowidzących. Wyniki tej oceny przedstawia rysunek 8.

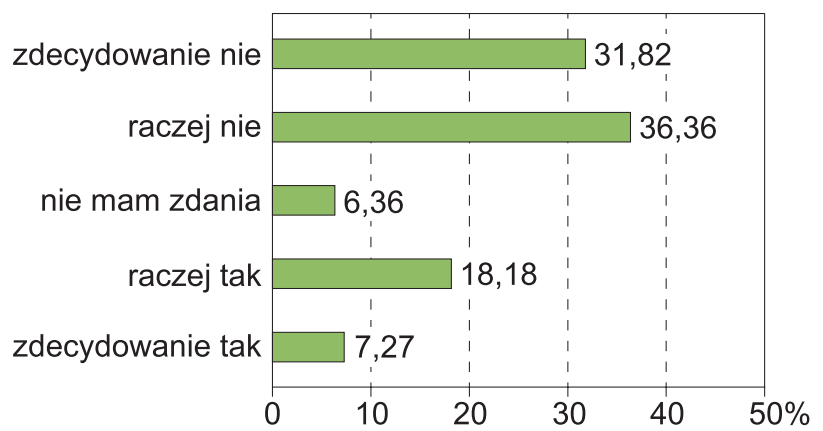

Rysunek 8. Ocena przystosowania zamieszkiwanego budynku do potrzeb osób z dysfunkcją wzroku (\%)

Źródło: opracowanie własne na podstawie badań przeprowadzonych w 2015 roku w siedzibie Fundacji ,Nie widzę problemu”.

Zasmucające jest, że ponad 68\% badanych uznało, że budynki, w których mieszkają, nie są dostosowane do ich potrzeb - około $32 \%$ uznało, że zdecydowanie nie są, a około $36 \%$, że raczej nie są dostosowane. Tylko nieco ponad 7\% osób może pochwalić się zamieszkaniem w pełni przystosowanym do potrzeb niepełnosprawnych osób budynku.

Respondentów poproszono również o wskazanie wydatków, które w ostatnim roku wzrosły w ich gospodarstwach domowych. W dużej części badanych wzrosły wydatki związane z użytkowaniem i wyposażeniem mieszkania. Aż 62\% 
osoby wskazały na wzrost wydatków związany z użytkowaniem mieszkania oraz opłat za media. U prawie $34 \%$ respondentów wzrosły wydatki na wyposażenie mieszkania i prowadzenie gospodarstwa domowego, $30 \%$ zakupiło duży sprzęt gospodarstwa domowego, na przykład pralkę, a 45,5\% drobny sprzęt gospodarstwa domowego, na przykład odkurzacz (rysunek 9).

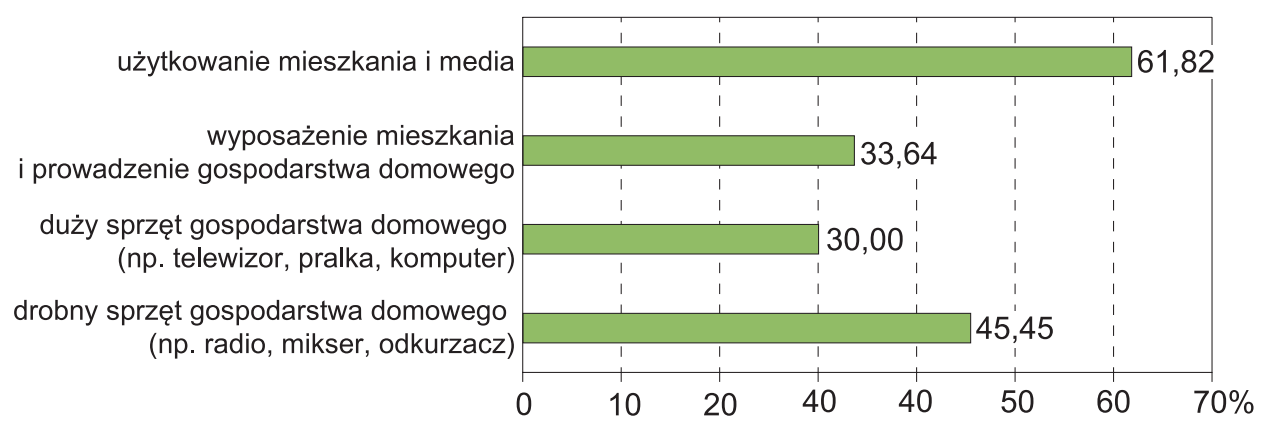

Rysunek 9. Obszary, w których zaobserwowano wzrost wydatków w gospodarstwach domowych w ostatnim roku (\%)

Źródło: opracowanie własne na podstawie badań przeprowadzonych w 2015 roku w siedzibie Fundacji „Nie widzę problemu”.

\section{Wnioski}

Opierając się na literaturze i przeprowadzonej analizie, można stwierdzić, iż warunki mieszkaniowe wpływają na jakość życia osób niepełnosprawnych w hierarchii ich potrzeb wysoko znajdują się przystosowanie mieszkania oraz poprawa warunków mieszkaniowych. Przyjęta hipoteza: niepełnosprawni dążą do poprawy jakości swojego życia poprzez zmianę warunków mieszkaniowych została częściowo potwierdzona. Pomimo iż tylko nieco ponad $40 \%$ respondentów posiada mieszkanie własnościowe, a o mieszkanie socjalne stara się tylko $23 \%$ nieposiadających takiego mieszkania, obserwuje się wzrost wydatków na duży oraz drobny sprzęt gospodarstwa domowego oraz inne wyposażenie mieszkania. Dodatkowo w latach 2010-2014 około 5,5\% respondentów zakupiło mieszkanie lub dom, a ponad 59\% sprzęt gospodarstwa domowego. Dla osób z dysfunkcją wzroku posiadanie miejsca, w którym czują się swobodnie, jest kluczowe. Zakup mieszkania to ogromny wydatek, oprócz tego w przypadku osób niepełnosprawnych przystosowanie mieszkania do ich potrzeb jest dużą inwestycją. Wsparciem może być pomoc w zakresie ubiegania się o mieszkanie socjalne - między innymi przyspieszenie i ułatwienie procedury wnioskowania o przyznanie takiego mieszkania, co prawdopodobnie zachęciłoby potrzebujących do składania wniosków. Posiadając mieszkanie socjalne (zaspokającą potrzebę ilościową), niewidomi i słabowidzący mają większy kapitał na przystosowanie go (zaspokojenie 
potrzeby jakościowej), gdyż na ich barkach nie spoczywa już ciężar zakupu nieruchomości. Zagadnienie jest tak ważne, że powinno się przeprowadzić szczegółowe badania i wprost zapytać osoby niepełnosprawne, co trzeba zrobić w kwestii poprawy warunków mieszkaniowych, aby wpłynąć na poprawę jakość ich życia.

\section{Bibliografia}

Borkowska M. (1997), Niepetnosprawność — definicja, podziat na grupy, [w:] W. Borkowska, Dziecko niepetnosprawne ruchowo, cz. 2. Usprawnianie ruchowe, Warszawa, s. 12-18.

Dębicka J., Mazurek E., Szalonka K. (2017), Postrzeganie jakości życia przez osoby niepetnosprawne, „Prace Naukowe Uniwersytetu Ekonomicznego we Wrocławiu” 483, s. 29-43.

Garbat M., Paszkowicz M.A. (2006), Jakość życia osób niepetnosprawnych w województwie lubuskim - diagnoza sytuacji materialno-bytowej, [w:] Jakość życia a niepetnosprawność. Konteksty psychopedagogiczne, red. Z. Palak, A. Lewicka, A. Bujnowska, Lublin.

Główny Urząd Statystyczny (2011), Narodowy Spis Powszechny.

Główny urząd Statystyczny (2014), Stan zdrowia ludności Polski.

Hołub J., Perenc J., Rosa G. (1997), Podstawy marketingu, Szczecin.

Hulek A. (1992), Świat ludziom niepetnosprawnym, Warszawa.

Kolman R. (2000), Zespoły badawcze jakości życia, „Problemy Jakości” 32(2), s. 2-5.

Lis P. (2005), Koncepcje polityki mieszkaniowej, https://www.researchgate.net/profile/Piotr Lis/publication/275713930_Koncepcje_polityki_mieszkaniowej/links/5544c6330cf234bdb21cd6d6/ Koncepcje-polityki-mieszkaniowej.pdf (dostęp: 15.06.2018).

Majewski T. (1995), Rehabilitacja zawodowa osób niepetnosprawnych, Warszawa.

Maslow A.H. (1954), Motivation and Personality, New York.

Nowakowski P., Charytonowicz J., Wybrane problemy jakości środowiska życia osób niepetnosprawnych http://idn.org.pl/Lodz/Mken/Mken\%202001/Referaty\%202001/3.pdf (dostęp: 19.06.2018).

Organizacja Narodów Zjednoczonych (1948), Powszechna deklaracja praw człowieka, Paryż.

Państwowy Fundusz Rehabilitacji Osób Niepełnosprawnych (2017), Badanie potrzeb osób niepełnosprawnych - Raport Końcowy.

Parchomiuk M., Byra S. (2006), Rodzaj niepetnosprawności a poczucie jakości życia, [w:] Jakość życia a niepetnosprawność. Konteksty psychopedagogiczne, red. Z. Palak, A. Lewicka, A. Bujnowska, Lublin.

Pawłowska K. (2009), Odczuwanie poziomu jakości życia przez osoby niepetnosprawne - przeglad wybranych badań, „Bezpieczeństwo Pracy: Nauka i Praktyka” nr 3, s. 14-17.

Perenc J., Rosa G., red. (2001), Zachowania nabywców, Szczecin.

Rosińczuk J., Szalonka K., Fugowska E., Sikora R. (2015), Pomiar jakości życia osób z dysfunkcją narządu wzroku, „Niepełnosprawność — Zagadnienia, Problemy, Rozwiązania” nr 3, s. 120-142.

Rudnicki L. (2004), Zachowania rynkowe nabywców. Mechanizmy i uwarunkowania, Kraków.

Rzempowska J. (2011), Socjomedyczne aspekty funkcjonowania młodych osób niepetnosprawnych w środowisku wiejskim, Poznań (praca doktorska).

Siedlecka A., Smarzewska A. (2013), Warunki mieszkaniowe jako miernik obiektywnej jakości życia osób niepetnosprawnych, „Zeszyty Naukowe Szkoły Głównej Gospodarstwa Wiejskiego. Ekonomika i Organizacja Gospodarki Żywnościowej” 102, s. 155-166.

Skrzypek E. (16.06.2018), Czynniki kształtujące jakość życia, http://idn.org.pl/lodz/mken/mken\%20 2001/referaty\%202001/14.pdf (dostęp: 20.06.2018).

Szawłowski K., Chojnacka-Szawłowska G. (1990), Medyczne i społeczne podstawy rehabilitacji, Gdańsk. 
Ustawa z dnia 12 marca 2004 roku o pomocy społecznej, Dz.U. 2004 Nr 64, poz. 593.

Ustawa z dnia 27 sierpnia 1997 roku o rehabilitacji zawodowej i społecznej oraz zatrudnianiu osób niepełnosprawnych, Dz.U. 1997 Nr 123, poz. 776.

Ustawa z dnia 8 marca 1990 roku o samorządzie gminnym, Dz.U. $1990 \mathrm{Nr}$ 16, poz. 95.

Wilmowska-Pietruszyńska A., Bilski D. (2010), ICF jako narzędzie ilościowej oceny naruszenia sprawności w orzeczeniu dla potrzeb zabezpieczenia spolecznego, „Orzecznictwo Lekarskie” 7(1), s. 1-13. 